\title{
Toxicity and repellency of essential oils to Zabrotes subfasciatus (Boheman) (Coleoptera, Chrysomelidae, Bruchinae) in Phaseolus vulgaris L.
}

\author{
Solange Maria de FRANÇA1 ${ }^{1}$, José Vargas de OLIVEIRA², Alberto Belo ESTEVES FILHO ${ }^{3}$, Cynara Moura de \\ OLIVEIRA $^{4}$
}

\begin{abstract}
The effects of tangerine (Citrus reticulata Blanco), lemon (Citrus medica limonum Lush), pear orange (Citrus sinensis $\mathrm{L}$. Osbeck), red copaiba (Copaifera langsdorffi Desf.), rosemary (Baccharis dracunculifolia De Candole), eucalyptus (Eucalyptus globulus Labillardière and E. citriodora Hook), lemongrass (Cymbopogon citratus Stapf.) and citronella (Cimbopogon nardus Linnaeus) oils at several concentrations on Zabrotes subfasciatus (Boheman) were studied. In toxicity tests, grains of Phaseolus vulgaris L. cv. Rajadinho were impregnated with oils and infested with adults of $Z$. subfasciatus up to 24 hours old. All tested oils were effective in reducing the viable egg-laying and adult emergence of this pest, in function of the concentrations used, highlighting E. citriodora and E. globulus oils which caused $100 \%$ effectiveness from $0.5 \mathrm{~mL} \mathrm{Kg}^{-1}$ concentration. In repellency tests, two arenas consisting of plastic containers, connected symmetrically to a central box by two plastic tubes were used. In one of the boxes, untreated beans were placed and on the other ones beans treated with each oil concentration were used. In the central box, five couples of $Z$. subfasciatus were released. Grains of $P$. vulgaris treated with oils of E. citriodora, C. citratus and $C$. oleifera reduced the attraction percentage of $Z$. subfasciatus adults, while the E. globulus increased this percentage. The percentages of reduced viable eggs ranged from $17.9 \%$ (C. medica limonum) to $93.3 \%$ (C. nardus), while the reduction on the number of emerged insects was $23.9 \%$ and $95.9 \%$, respectively for these same oils.
\end{abstract}

KEYWORDS: Botanical insecticides, bean weevil, bioactivity, behavioral effect.

\section{Toxicidade e repelência de óleos essenciais a Zabrotes subfasciatus (Boheman) (Coleoptera, Chrysomelidae, Bruchinae) em grãos de Phaseolus vulgaris $\mathrm{L}$.}

RESUMO

Estudaram-se os efeitos dos óleos de tangerina 'Cravo' (Citrus reticulata Blanco), limáo-siciliano (Citrus medica limonum Lush), laranja 'Pêra' (Citrus sinensis L. Osbeek), copaíba-vermelha (Copaifera langsdorffi Desf.), alecrim-do-campo (Baccharis dracunculifolia De Candole), eucalipto (Eucalyptus globulus Labillardière e Eucalyptus citriodora Hook), capim-santo (Cymbopogon citratus Stapf.) e citronela (Cymbopogon nardus L.), em diversas concentraçốes, sobre Zabrotes subfasciatus (Boheman). Nos testes de toxicidade, grãos de Phaseolus vulgaris L. cv. Rajadinho foram impregnados com os óleos e infestados com adultos de $Z$. subfasciatus com até 24 horas de idade. Todos os óleos foram eficientes na redução da postura de ovos viáveis e na emergência de adultos desta praga, em função das concentraçóes utilizadas, destacando-se E. citriodora e E. globulus, que a partir da concentração de $0,5 \mathrm{~mL} \mathrm{Kg}^{-1}$ já causaram $100 \%$ de eficácia. Nos testes de repelência utilizaram-se arenas compostas por dois recipientes plásticos, interligados simetricamente a uma caixa central por dois tubos plásticos. Numa das caixas colocaram-se grãos de feijão não tratados e, na outra, feijóes tratados com cada uma das concentraçóes de óleo testadas. Na caixa central foram liberados cinco casais de $Z$. subfasciatus. Os grãos de $P$. vulgaris tratados com os óleos de $E$. citriodora, $C$. citratus e $C$. oleifera reduziram a porcentagem de adultos de $Z$. subfasciatus atraídos, enquanto o óleo de E. globulus aumentou essa porcentagem. As percentagens de redução de ovos viáveis variaram de $17,9 \%$ (C. medica limonum) a 93,3\% (C. nardus), enquanto que a redução do número de insetos emergidos foi de 23,9\% e 95,9\%, respectivamente, para esses mesmos óleos.

PALAVRAS-CHAVE: Inseticidas botânicos, caruncho-do-feijão, bioatividade, efeito comportamental.

1, 2, 3, 4 Universidade Federal Rural de Pernambuco, Departamento de Agronomia, Área de Fitossanidade, Laboratório de Entomologia Agrícola, Rua Dom Manoel de Medeiros, S/n, Dois Irmãos, Recife - PE, 52171-030. E-mails: solangeufrpe@yahoo.com.br; vargasoliveira@uol.com.br; betobelo@gmail.com; cynara_moura@yahoo.com.br 


\section{INTRODUCTION}

The Bruchinae are distributed in almost all continents except in Antarctica and New Zealand, being the largest number of species found in the Neotropical Region (Kingsolver 2002). The species of stored products may have originated in various regions of the world, but due to transport from one country or continent to another together with the goods they have become cosmopolitan. It is believed that many of these species occur in populations, geographic subspecies or breeds that differ in food preference, climatic conditions and susceptibility to insecticides (Hill 1990).

Zabrotes subsfasciatus (Boheman) (Coleoptera, Chrysomelidae, Bruchinae) is a major primary pest of the stored bean Phaseolus vulgaris L. in tropical regions. It infests grains and seeds in storage units causing quantitative losses (weight loss), which can be quite variable depending on the degree of infestation and susceptibility of seeds or grains from such species. Qualitative losses are more difficult to be assessed, and they consist of vigor and germination reduction, changes in physical appearance, nutritional losses, presence of insects, mites and their fragments, fungal infection and mycotoxin contamination, impurities and other foreign materials (Lazzari 1997).

Botanical insecticides containing different compounds derived from plants secondary metabolism have been tested in order to control this pest in stored beans with promising results (Weaver et al. 1994; Oliveira and Vendramim 1999; Barbosa et al. 2002; Paranhos et al. 2005, Santos et al. 2007; Silva et al. 2008; Paul et al. 2009), as an alternative to protective chemical insecticides, which are generally more toxic and likely to cause harmful effects to applicators, consumers and the environment. Among the most promising compounds, the monoterpenes and its analogues are remarkable. They are quite volatile, lipophilic and act by contact, ingestion and fumigation, causing mortality, repellence and effects on the insect biology, physiology and behavior. They can be used as dry powders, extracts, essential oils and oil emulsion (Brito et al. 2006; Isman 2006; Rajendran and Sriranjini 2008; Selase and Getu 2009).

This study aimed to evaluate the effects of some essential oils on mortality, number of viable eggs and emergence of $Z$. subfasciatus, as well as its repellency to adults on grains of P. vulgaris.

\section{MATERIAL AND METHODS}

Zabrotes subfasciatus rearing. Insects were reared for several generations on grains of $P$. vulgaris cv. Rajadinho in the Agricultural Entomology Laboratory of the Federal Rural University of Pernambuco (UFRPE), Brazil, at $27.1 \pm$ $1{ }^{\circ} \mathrm{C}, 74.2 \pm 5.3 \%$ of $\mathrm{RH}$ (Humidity Relative) and $12 \mathrm{~h}$ of photophase, stored in glass containers, sealed with perforated plastic lids and lined with fine cloth to allow gas exchange. Adults were confined for six days, subsequently they were removed, and the grains stored until adult emergence.

Infestation removal and hygroscopic equilibrium. Beans properly selected (broken grains with impurities were eliminated) used for rearing and experiments were placed in plastic bags and kept in a freezer at $-5^{\circ} \mathrm{C}$ for seven days to eliminate possible insect infestation from field. After removal from the freezer, the grains were transferred to glass flasks and kept in laboratory temperature, which varied between 26 and $28{ }^{\circ} \mathrm{C}$ for seven days in order to reach the hygroscopic equilibrium. The equilibrium with air humidity is normally reached after seven days.

Origin of plant essential oils. Oils from tangerine (Citrus reticulata Blanco) (Rutaceae), lemon (Citrus medica limonum Lush) (Rutaceae), pear orange (Citrus sinensis L. Obesck) (Rutaceae), red copaiba (Copaifera langsdorffii Desf.) (Fabaceae), rosemary (Baccharis dracunculifolia De Candole) (Asteraceae), eucalyptus (Eucalyptus globulus Labillardière and Eucalyptus citriodora Hook.) (Myrtaceae), lemongrass (Cymbopogon citratus Stapf.) (Poaceae), and citronella (Cymbopogon nardus (L.) (Poaceae) were purchased from Aromalandia Ltd. (Belo Horizonte, MG, Brazil).

Contact toxicity tests. Experiments were conducted at $30.1 \pm 1.8{ }^{\circ} \mathrm{C}, 67.2 \pm 4.7 \%$ Relative Humidity and $12 \mathrm{~h}$ photophase. Oils were tested at the concentrations 0, 0.5, 1.0, $1.5,2.0$ and $2.5 \mathrm{~mL} \mathrm{~kg}^{-1}$ grains of $P$. vulgaris $\mathrm{cv}$. Rajadinho, selected in preliminary experiments. The treatment of grains with the essential oils was performed using plastic containers. Oils were manipulated using an automatic pipette and then the containers were manually agitated during two minutes. Each $20 \mathrm{~g}$ portion of $P$. vulgaris grains was infested with five couples of $Z$. subfasciatus up to $24 \mathrm{~h}$ old. Six days after the confinement, live and dead insects were counted and then discarded. The quantification of viable and unviable eggs was performed after 16 days, examining all grains of each plot under stereomicroscope. The viable eggs are opaque whereas the non-viable are translucent. Adult emergences were measured at 40 days after infestation. The oils were separately tested in a fully randomized design, consisting of six treatments and six replications. Results were submitted to regression analysis, being selected those equations that best represented the biological response, based on its significance $\left(\mathrm{F}\right.$ and $\mathrm{P}$ ) and higher coefficient of determination $\left(\mathrm{R}^{2}\right)$. All tests were conducted using the statistical program SAS version 8.02 (SAS Institute 2001).

Repellency tests. The same oils used above were studied. The experiments were conducted at the same range of temperature, relative humidity and photoperiod. Arenas consisting of two plastic containers, connected symmetrically 
to a central box by two plastic tubes were used. In one of the boxes, $20 \mathrm{~g}$ of beans without oil (control) were placed and on the other one, the same amount of treated grains was used. In the central box five couples of $Z$. subfasciatus up to $24 \mathrm{~h}$ old were released. The oils were tested separately in a complete randomized design, consisting of two treatments: the best oil concentration in the no-choice test and the control, using 10 replicates. After six days, insects maintained in each container were counted for repellency evaluation, and then discarded; the beans were stored in plastic containers. The viable and unviable eggs were evaluated in all grains of the plot after 16 days, and emerged adults quantified at 40 days after infestation.

Percentages of adults attracted to the control and to each concentration of oil were submitted to the analysis of choice frequency and evaluated by the chi-square test using the SAS. The number of viable eggs and the number of emerged insects were subjected to analysis of variance; data from $B$. dracunfolia, C. citratus, C. langsdorffi, C. nardus e C. reticulata were transformed into square root of $\mathrm{x}+0.5$, in order to achieve homogeneity in variances, and analyzed by the $t$ test. The average percentage reduction of oviposition and adult emergence was calculated using the formula adapted from Obeng-Ofori (1995): $\mathrm{PR}=[(\mathrm{NC}-\mathrm{NT}) /(\mathrm{NC}+\mathrm{TN}) \times 100]$, where $\mathrm{PR}=$ average percentage of reduction in oviposition and/or emergence, $\mathrm{NC}=$ average number of eggs and/or emerged insects in the control, and NT = average number of eggs and/or emerged insects in the treatment.

\section{RESULTS AND DISCUSSION}

Contact toxicity tests. Mortality rates of $Z$. subfasciatus on grains of $P$. vulgaris treated with plant essential oils varied with both oil type and concentration used. Regression equations (significant, $\mathrm{P} \leq 0.05$ ) that explain oils performance on adult mortality, number of viable eggs, and emerged adults were obtained (Table 1). No significant regression equations were established for the essential oils of E. globulus, E. citriodora,
C. nardus, C. citratus, B. drancunculifolia and C. sinensis, as all of them caused $100 \%$ mortality rates and total reduction on the number of viable eggs and emerged insects from the lowest concentration $\left(0.5 \mathrm{~mL} \mathrm{~kg}^{-1}\right.$ beans) not fitting the statistical model. Although presenting 100\% efficiency, the results demonstrated the need to test these oils at lower concentrations, for the establishment of regression equations.

In Brazil there are only four products registered for control of $Z$. subfasciatus in stored beans, being three inorganic precursors of phosphine fumigants (extremely toxic), used to curative control, and a pyrethroid (deltamethrin), as a protective insecticide (AGROFIT 2011). Hence, the results of this work, with essential oils that may features less impact on environment and health of applicators and consumers, are crucial as alternative products.

Some studies have shown the bioactivity of plants on Z. subfasciatus. Black pepper powders [Piper nigrum (L.)] (Piperaceae), cinnamon leaves (Cynnamomum zeylanicum Blume) (Lauraceae) (Oliveira et al. 1999) and neem oil (Azadirachta indica A. Juss) (Meliaceae) (Barbosa et al. 2002) were effective on $Z$. subfasciatus. According to Mazzonetto (2002), the powders of Chenopodium ambrosioides L. (Chenopodiaceae), Mentha pulegium L. (Lamiaceae), Ocimum basilicum L. (Lamiaceae), and rue (Ruta graveolens L.) (Rutaceae) caused $100 \%$ mortality rates and prevented oviposition of $Z$. subfasciatus on P. vulgaris grains. Crushed leaves of Tetradenia riparia (Hochst.) (Lamiaceae) species at $4 \%$ concentration reduced fertility and fecundity of $Z$. subfasciatus on P. vulgaris grains (Weaver et al. 1991). The root powder of Senecio salignus DC. (Asteraceae) showed contact toxicity on $Z$. subfasciatus, with $\mathrm{LC}_{50}$ (Lethal Concentration 50) ranging between $0.11 \%$ and $0.08 \%$, but it had neither fumigant nor repellent effect (López-Pérez et al. 2007). The linalool compound, one of the major components of Ocimum canum L. (Lamiaceae) caused $98 \%$ and $100 \%$ mortality rates to adults of $Z$. subfasciatus at concentrations of 500 and 700 $\mu \mathrm{g} \mathrm{cm}{ }^{-2}$, respectively (Weaver $e t a l .1991$ ).

Table 1 - Equations for mortality rates (\%), number of viable eggs and adult emergence, and their respective adjusting parameters (F, Fisher test; $P$ value and significance; $\mathrm{R}^{2}$, coefficient of determination) of $Z$. subfasciatus submitted to $P$. vulgaris beans treated with several plant essential oils. Temp: $30.1 \pm 1.82$ ${ }^{\circ} \mathrm{C}, \mathrm{RH}$ (Relative Humidity): $67.2 \pm 4.68 \%$, and $12 \mathrm{~h}$ photophase.

\begin{tabular}{|c|c|c|c|c|}
\hline Treatments & Parameters & Equations & $F^{P}$ & $R^{2}$ \\
\hline \multirow{3}{*}{ Copaifera langsdorffii } & Mortality & $\hat{y}=2.30+42.38 x$ & $157.96^{<0.0001}$ & 0.82 \\
\hline & Number of viable eggs & $\hat{y}=126.24+165.57 x-47.94 x^{2}$ & $107.24^{<0.0001}$ & 0.87 \\
\hline & Emergence & $\hat{y}=114.76-151.85 x+44.13 x^{2}$ & $112.44<0.0001$ & 0.87 \\
\hline \multirow{3}{*}{ Citrus reticulata } & Mortality & $\hat{y}=4.70-21.63 x+17.26 x^{2}$ & $22.11^{<0.0001}$ & 0.57 \\
\hline & Number of viable eggs & $\hat{y}=147.60-66.70 x$ & $187.92^{<0.0001}$ & 0.85 \\
\hline & Emergence & $\hat{y}=114.59-52.07 x$ & $151.23^{<0.0001}$ & 0.82 \\
\hline \multirow{3}{*}{ Citrus medica limonum } & Mortality & $\hat{y}=2.85-27.19 x+26.19 x^{2}$ & $139.79<0.0001$ & 0.89 \\
\hline & Number of viable eggs & $\hat{y}=150.04-67.20 x$ & $259.22^{<0.0001}$ & 0.88 \\
\hline & Emergence & $\hat{y}=119.35-53.39 x$ & $219.63^{<0.0001}$ & 0.86 \\
\hline
\end{tabular}


The fumigant effect of essential oils has been also investigated, opening new perspectives in the control of stored grain pests with plants of the families Apiaceae, Lamiaceae, Lauraceae and Myrtaceae, aiming mainly to control immature and adults of Tribolium castaneum Herbst, Rhyzopertha dominica Fabricius, Sitophilus oryzae Linnaeus and Sitophilus zeamais Motschulsky (Rajendran and Sriranjini 2008), and that can be tested for the management of $Z$. subfasciatus. Essential oils from plants of the genus Eucalyptus reduced the proportion of viable eggs and emerged adults of $Z$. subfasciatus due to its fumigant effect (Brito et al. 2006). The essential oil from leaves and stems of Croton grewioides Baill. (Euphorbiaceae) also presented fumigant effect to adults of $Z$. subfasciatus, with $\mathrm{LC}_{50}$ values of 4 and $13.77 \mu \mathrm{l} / \mathrm{L}$ air, respectively (Silva et al. 2008).
Repellency tests. The oils of $C$. citratus $\left(\chi^{2}=10.17 ; \mathrm{P}<\right.$ $0.01), C$. angsdorffii $\left(\chi^{2}=9.22 ; \mathrm{P}=0.002\right)$ and $E$. citriodora $\left(\chi^{2}=8.33 ; \mathrm{P}<0.0001\right)$ reduced the number of adults of $Z$. subfasciatus attracted to $P$. vulgaris beans compared to the control; however, E. globulus $\left(\chi^{2}=26.14 ; \mathrm{P}<0.001\right)$ increased the attraction of adults (Figure 1). Treatments of C. reticulata $\left(\chi^{2}=0.98 ; \mathrm{P}=0.32\right), C$. medica limonun $\left(\chi^{2}\right.$ $=1.74 ; \mathrm{P}=0.18), C$. nardus $\left(\chi^{2}=0.02 ; \mathrm{P}=0.88\right)$ and $B$. drancunculifolia $\left(\chi^{2}=2.44 ; \mathrm{P}=0.11\right)$ were considered neutral, since $Z$. subfasciatus showed indifferent choice. The oils of $B$. drancunculifolia ( $\mathrm{DF}=18, \mathrm{t}=-3.06, \mathrm{P}<0.006), C$. citratus $(\mathrm{DF}=11.5, \mathrm{t}=-10.59 \mathrm{P}<0.0001)$, C. langsdorffi $(\mathrm{GL}=$ $11.5, \mathrm{t}=10.14 \mathrm{P}<0.0001), C$. nardus $(\mathrm{DF}=9.28, \mathrm{t}=8.97$ $\mathrm{P}<0.0001)$, E. citriodora $(\mathrm{DF}=18, \mathrm{t}=11.03 \mathrm{P}<0.0001)$, and $C$. reticulata $(\mathrm{DF}=10.8, \mathrm{t}=-2.64, \mathrm{P}<0.02$ ) significantly reduced the number of viable eggs when compared with the control (Table 2). C. nardus did not reduce the number of

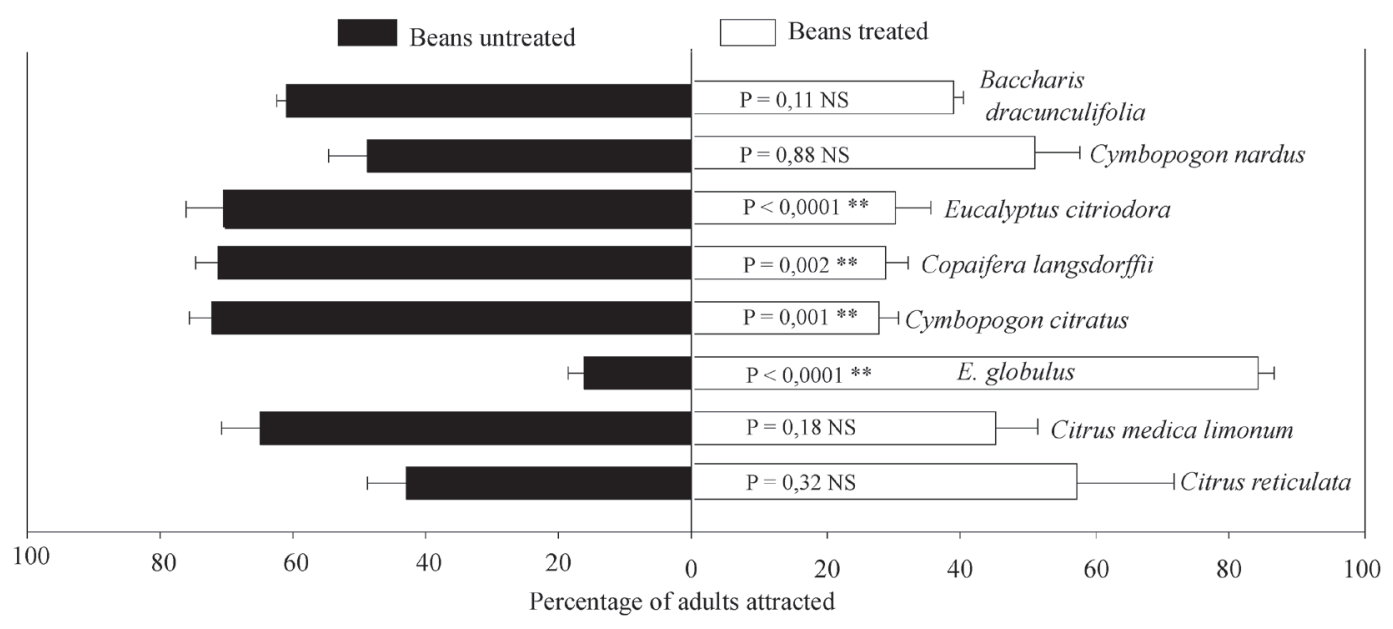

Figure 1 - Percentage of adults of Zabrotes subfasciatus attracted to Phaseolus vulgaris beans treated and untreated with essential oils. ${ }^{*}$ Statistically significant by $\chi^{2}=$ chi-square test. NS $=$ Not significant.

Table 2 - Effect of plant essential oils on egg-laying of viable eggs of Z. subfasciatus in grains of P.vulgaris. Free-choice Test.

\begin{tabular}{|c|c|c|c|c|}
\hline \multirow{2}{*}{ Treatment } & \multirow{2}{*}{ Conc. $\left(\mathrm{mL} \mathrm{Kg}{ }^{-1}\right)$} & \multicolumn{2}{|c|}{ Oviposition $\left( \pm \mathrm{SE}^{-1}\right)$} & \multirow{2}{*}{ Reduction $(\%)$} \\
\hline & & Control & Oil & \\
\hline Baccharis dracunculifolia & 0.5 & $61.54 \pm 12.25^{\star}$ & $15.53 \pm 7.88$ & 59.7 \\
\hline Cymbopogon citratus & 0.5 & $79.26 \pm 6.49$ * & $3.92 \pm 2.51$ & 90.6 \\
\hline C. nardus & 0.5 & $70.36 \pm 7.70$ * & $2.43 \pm 0.98$ & 93.3 \\
\hline Copaifera langsdorffii & 0.5 & $86.90 \pm 7.24$ * & $8.25 \pm 2.70$ & 82.7 \\
\hline Eucalyptus citriodora & 0.5 & $92.94 \pm 5.79$ * & $5.83 a \pm 5.02$ & 88.2 \\
\hline E. globulus & 0.5 & $51.74 \pm 8.75$ & $26.51 \pm 8.84$ & 32.2 \\
\hline Citrus medicum limonun & 1.5 & $44.60 \pm 7.59$ & $30.98 \pm 6.83$ & 17.9 \\
\hline C. reticulata & 1.5 & $66.15 \pm 14.63^{*}$ & $29.89 \pm 4.59$ & 37.75 \\
\hline
\end{tabular}

* Significant means in t test $(P \geq 0.05)$ compared to control.

1 Standard Error. 
adults attracted to $P$. vulgaris beans treated with this essential oil, but it was the most effective in reducing the egg-laying of viable eggs (93.3\%), followed by C. citratus (90.6\%), E. citriodora (88.2\%) and C. angsdorffii (82.7\%); for the other oils, percentages of reduction ranged between $17.9 \%$ and $59.7 \%$ (Table 2). This behavior was also observed in the adult emergence of $Z$. subfasciatus for $C$. nardus $(\mathrm{DF}=9.16, \mathrm{t}=8.51$, $\mathrm{P}<0.0001)$, C. citratus $(\mathrm{DF}=11.3, \mathrm{t}=-9.61, \mathrm{P}<0.0001), E$. citriodora $(\mathrm{DF}=18, \mathrm{t}=9.68, \mathrm{P}<0.0001)$, C. oleifera $(\mathrm{DF}=$ $11, \mathrm{t}=8.21, \mathrm{P}<0.0001)$ and $B$. dracunculifolia $(\mathrm{DF}=12.7$, $\mathrm{t}=-3.37, \mathrm{P}<0.005)$ which reduced emergence in $95.9 \%$, $92.4 \%, 88.4 \%, 85 \%$ and $72.4 \%$, respectively. For the other oils the reduction ranged from about $23.97 \%$ to $37.5 \%$ (Table 3). The oils of $C$. medica limonun ( $\mathrm{DF}=18, \mathrm{t}=-1.38, \mathrm{P}<$ $0.18 ; \mathrm{DF}=18, \mathrm{t}=-1.19, \mathrm{P}<0.25)$ e E. globulus $(\mathrm{DF}=18$, $\mathrm{t}=1.62, \mathrm{P}<0.12 ; \mathrm{DF}=18, \mathrm{t}=1.18, \mathrm{P}<0.09)$ caused no significant reduction on the number of viable eggs, neither on the number of $Z$. subfasciatus adults emerged.

The repellency is an important feature of both plant essential oils and powders for the management of $Z$. subfasciatus, since they play a role directly in the reduction of egg-laying and hence the emergence of adults, making difficult the establishment of pest populations in grain storage units. The oils of cinnamon leaves and bay leaves (Laurus nobilis L.) at $2.5 \mathrm{~mL} \mathrm{~kg}^{-1}$ grains of $P$. vulgaris exerted repellent effect over $70 \%$ on adults of $Z$. subfasciatus (Oliveira and Vendramim 1999). Essential oils from Lippia origanoides Kunth, E. citriodora, and Tagetes lucida Cav. collected in Colombia caused repellency to $S$. zeamais (Nerio et al. 2009). Oils extracted from Laurus nobilis L., Citrus bergamia (Risso) Wight \& Arn., Foeniculum vulgare Mill., and Lavandula hibrida L. were repellent to adults of S. zeamais, Cryptolestes

Table 3 - Effect of plant essential oils on the emergence of adults of $Z$. subafasciatus in grains of $P$. vulgaris. Free-choice Test.

\begin{tabular}{|c|c|c|c|c|}
\hline \multirow{2}{*}{ Treatment } & \multirow{2}{*}{$\begin{array}{l}\text { Conc. (mL } \\
\left.\mathrm{Kg}^{-1}\right)\end{array}$} & \multicolumn{2}{|c|}{ Emergence $\left( \pm \mathrm{SE}^{1}\right)$} & \multirow{2}{*}{$\begin{array}{l}\text { Reduction } \\
\text { (\%) }\end{array}$} \\
\hline & & Control & Oil & \\
\hline $\begin{array}{c}\text { Baccharis } \\
\text { dracunculifolia }\end{array}$ & 0.5 & $50.87 \pm 12.22 *$ & $8.14 \pm 5.69$ & 72.4 \\
\hline $\begin{array}{c}\text { Cymbopogon } \\
\text { citratus }\end{array}$ & 0.5 & $70.82 \pm 6.67^{*}$ & $2.79 \pm 2.4$ & 92.4 \\
\hline C. nardus & 0.5 & $63.80 \pm 7.64^{*}$ & $1.32 \pm 0.73$ & 95.9 \\
\hline $\begin{array}{l}\text { Copaifera } \\
\text { langsdorffii }\end{array}$ & 0.5 & $74.22 \pm 7.85^{\star}$ & $6.02 \pm 2.66$ & 85.0 \\
\hline $\begin{array}{l}\text { Eucalyptus } \\
\text { citriodora }\end{array}$ & 0.5 & $79.03 \pm 6.14^{*}$ & $4.86 \pm 4.22$ & 88.4 \\
\hline E. globulus & 0.5 & $43.76 \pm 8.80$ & $25.61 \pm 7.39$ & 26.2 \\
\hline $\begin{array}{l}\text { Citrus medica } \\
\text { limonun }\end{array}$ & 1.5 & $36.14 \pm 7.84$ & $23.93 \pm 7.18$ & 23.97 \\
\hline C. reticulata & 1.5 & $9.32 \pm 13.17^{*}$ & $26.99 \pm 4.16$ & 37.46 \\
\hline
\end{tabular}

* Significant means in t test $(P \geq 0.05)$ compared to control. ${ }^{1}$ Standard Error. ferrugineus Stephens, and larvae of Tenebrio molitor L. (Cosimi et al. 2009). Nerio et al. (2010) published a recent review about repellency activity of essential oils. This author noted that the compounds of Cymbopogon spp., Ocimum spp. and Eucalyptus spp. were the most repellent to several stored product pests. Due to the own insecticidal properties, plant essential oils can be very useful in integrated management of $Z$. subfasciatus in stored beans, mainly in small farms, as a promising alternative to synthetic chemical insecticides. However, further studies are a priority regarding to the collecting processes, drying, storage and preparation of plant material, quantification of bioactive compounds, toxicology studies, formulations, and safety. The main goal is to provide consumers with high-quality beans without the presence of toxic waste.

\section{CONCLUSIONS}

1) Oils of $C$. reticulata, $C$. medica limonum, $C$. sinensis, $C$. langsdorffi, B. dracunculifolia, E. globulus and E. citriodora, C. citratus, $C$. nardus significantly reduced viable egg-laying and the adult emergence of $Z$. subfasciatus, depending on the concentrations.

2) C. citratus, E. citriodora and C. oleifera showed the highest repellent effect on adults of this pest.

3) E. globulus showed an attractive effect on adults of $Z$. subfasciatus.

\section{ACKNOWLEDGEMENTS}

We thank National Council of Technological and Scientific Development - CNPq for the research financial support.

\section{REFERENCES}

AGROFIT - Sistema de agrotóxicos fitossanitários. 2011. Disponível em: http://agrofit.agricultura.gov.br/agrofit_cons/principal_ agrofit_cons. Acesso: 13/10/2011.

Barbosa, F.R.; Yokoyama, M.; Pereira, P.A.A.; Zimmermann, F.J.P. 2002. Controle do caruncho-do-feijoeiro Zabrotes subfasciatus com óleos vegetais, munha, matérias inertes e malathion. Pesquisa Agropecuária Brasileira, 37: 1213-1217.

Brito, J.P.; Baptistussi, R.C.; Funichello, M.; Oliveira, J.E.; De Bortoli, S.A. 2006. Efeito de óleos essenciais de Eucaliptus spp. sobre Zabrotes subfasciatus (Boh., 1833) (Coleoptera: Bruchidae) e Callosobruchus maculatus (Fabr., 1775) (Coleoptera: Bruchidae) em duas espécies de feijōes. Boletin Sanidad Vegetal Plagas, 32: 573-580.

Cosimi, S.; Rossi, E.; Cioni, P.L.; Canale, A. 2009. Bioactivity and qualitative analysis of some essential oils from Mediterranean plants against stored-product pests: evaluation of repellency against Sitophilus zeamais Matschulsky, Cryptolestes ferrugineus 
Stephens and Tenebrio molitor (L.). Journal of Stored Products Research, 45: 125-132.

Hill, D.S. 1990. Pest of stored products and their control. Boca Raton: CRC, 274 p.

Isman, M.B. 2006. Botanical insecticides, deterrents, and repellents in modern agriculture and an increasingly regulatory world. Annual Review of Entomology, 51: 45-66.

Kingsolver, J.M. 2002. Bruchidae. p.602-608. In: Arnett, R.H.; Thomas, M.C.; Skelley, P.E.; Frank, J.H. (Eds.). Amarican Beetles. Polyphaga: Scarabaeoidea though Curculionoidea. Boca Raton: CRC.

Lazzari, F.A. 1997. Umidade, fungos e micotoxinas na qualidade de sementes, grãos e raçôes. Curitiba: Edição do autor, 134 p.

López-Pérez, E.; Rodríguez-Hernández, C.; Ortega-Arenas, L.D.; Garza-García, R. 2007. Actividad biológica de la raíz de Senecio salignus contra Zabrotes subfasciatus en frijol almacenado. Agrociência, 41: 95-102.

Mazzonetto, F. 2002. Efeito de genótipos de feijoeiro e de pós de origem vegetal sobre Zabrotes subfasciatus (Boh.) e Acanthoscelides obtectus (Say) (Col.: Bruchidae). Tese de doutorado, Escola Superior de Agricultura "Luiz de Queiroz", USP, Piracicaba, 134p.

Nerio, L.S.; Olivero-Verbel, J.; Stashenko, E. 2009. Repellent activity of essential oils from seven aromatic plants grown in Colombia against Sitophilus zeamais Motschulsky (Coleoptera). Journal of Stored Products Research, 45: 212-214.

Nerio, L.S.; Olivero-Verbel, J.; Stashenko, E. 2010. Repellent activity of essential oils: a review. Bioresource Technology, 101:372-378.

Obeng-Ofori, D. 1995. Plant oils as grain protectants against infestations of Cryptolestes pussilus and Rhyzopertha dominica in stored grain. Entomologia Experimentalis et Applicata, 77: 133-139.

Oliveira, J.V.; Vendramim, J.D. 1999. Repelência de óleos essenciais e pós vegetais sobre adultos de Zabrotes subfasciatus (Boh.) (Coleoptera: Bruchidae) em sementes de feijoeiro. Anais da Sociedade Entomológica do Brasil, 28: 549-555.

Oliveira, J.V.; Vendramim, J.D.; Haddad, M.L. 1999. Bioatividade de pós vegetais sobre o caruncho do feijão em grãos armazenados. Revista de agricultura, 74: 217-227.

Paranhos, B.A.J.; Custódio, C.C.; Neto, N.B.M.; Rodrigues, A.S. 2005. Extrato de nim e cravo da índia no controle de Zabrotes subfasciatus (Boheman) (Coleoptera: Bruchidae) em sementes de feijāo armazenado. Colloquim Agrariae, 1: 1-7.
Paul, U.V.; Lossini, J.S.; Edwards, P.J.; Hilbeck, A. 2009. Effectiveness of produsts from four locally grown plants for the management of Acanthoscelides obtectus (Say) and Zabrotes subfasciatus (Boheman) (Coleoptera: Bruchidae) in stored beans under laboratory and farm conditions in Northern Tanzania. Journal of Stored Products Research, 45: 97-107.

Rajendran, S.; Sriranjini,V. 2008. Plant products as fumigants for stored-product insect control. Journal of Stored Products Research, 44: 126-135.

Santos, M.R.A.; Lima, R.A.; Silva, A.G.; Fernandes, C.F.; Lima, D.K.S.; Sallet, L.A.P.; Teixeira, C.A.D.; Facundo,V. A. 2007. Atividade inseticida do óleo essencial de Schinus terebinthifolis Raddi sobre Acanthoscelides obtectus Say e Zabrotes subfasciatus Boheman. Porto velho, RO: Embrapa,13 p. (Boletim de Pesquisa e Desenvolvimento, 48).

SAS Institute. 2001. SAS/STAT User's guide, version 8.02, TS level 2MO. SAS Institute Inc., Cary, NC.

Selase, A.G.; Getu, E. 2009. Evaluation of botanical plants powders against Zabrotes subfasciatus (Boheman) (Coleoptera: Bruchidae) in stored haricot beans under laboratory condition. African Journal of Agricultural Research, 4: 1073-1079.

Silva, C.G.V.; Zago, H.B.; Santos Júnior, H.J.G.; Camara, C.A.G.; Oliveira, J.V.; Barros, R.; Schwartz, M.O.E.; Lucena, M.F.A. 2008. Composition and insecticidal activity of the essential oil of Croton grewioides Baill. against Mexican Bean Weevil. (Zabrotes subfasciatus Boheman). Journal of Essential Oil Research, 20: 179-182.

Weaver, D.K.; Wells, C.D.; Dunkel, F.; Bertsch, W.; Sing, S.E.; Sriharan, S. 1994. Inseticidal activity of floral, foliar, and root extracts of Tagetes minuta (Asterales: Asteraceae) against adult Mexican bean weevils (Coleoptera: Bruchidae). Journal of Economic Entomology, 87: 1718-1725.

Weaver, D.K.; Dunkel, F.V.; Ntezurubanza, L.; Jackson, L.; Stoch, D.T. 1991. The efficacy of linalool, a major component of freshly-milled Ocimum canum Sims (Lamiaceae), for protection against postharvest damage by certain stored product Coleoptera. Journal of Stored Products Research, 27: 213-220.

Recebido em: 19/04/2011

Aceito em: 19/11/2011 